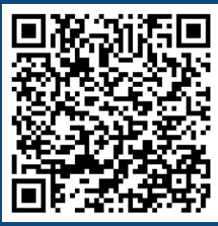

Keywords:

Landscape corridor

Least-cost path

Resistance map

North Central Anatolia

Turkey

Lynx lynx

Historic:

Received 18/1 1/2019

Accepted 05/02/2020

Correspondence: auozcan@karatekin.edu.tr
Alı Uğur Özcan ${ }^{\mathrm{a}+}$, Pakize Ece Erzin ${ }^{\mathrm{b}}$

\section{ASSESSMENT OF GIS-ASSISTED MOVEMENT PATCHES USING LCP FOR LOCAL SPECIES: NORTH CENTRAL ANATOLIA REGION, TURKEY.}

ÖZCAN, A. U.; ERZIN, P. E. Assessment of gis-assisted movement patches usıng lcp for local species: north central anatolia regıon, Turkey. CERNE, v. 26, n. I, p. I30-I39, 2020.

\section{HIGHLIGHTS}

The least cost path analysis was used to determine the location of the ecological corridors according to the resistance for a particular species.

The study area is the most edge point for lynx in steppe forests.

Six corridors were identified.

The study methodology will contribute to ecological corridors that will be planned in Turkey.

\section{ABSTRACT}

As a result of the fragmentation and degradation of forests, the connectivity of natural habitats has been decreasing. Thus, problems in gene flow in wildlife have begun to arise. The connection of landscape patches with corridors is now an important subject of landscape planning. Central Anatolia has been affected by forest fragmentation due to its fragile ecologies. The purpose of this study was i) to identify the spatial location of landscape corridors in order to create ecological networks among the natural landscape reserves in the Northern Central Anatolia Region and ii) to develop a guideline that can be applied for landscape connectivity in fragmentation areas. Landscape resistances were determined according to the target species ( $\operatorname{lyn} x \operatorname{lynx}$ ) and a resistance map was formed. Corridors were determined by using Least-cost path (LCP) approach with GIS. As a result, six corridors and major barriers were identified among the core areas and north forests. The methodology and results of this study has promising potential, which can be considered by experts, planners, and researchers in Turkey and others regions of the world as references for identifying and planning optimal patches for habitat sustainability. 


\section{INTRODUCTION}

Anthropogenic formations, such as agricultural areas, human settlements, and roads, are the main causes for the fragmentation of forests, as well as for the reduction of biodiversity. Many wild animals can migrate long distances and move through the landscape for breeding, nesting or seeking shelter. Wild animals can travel in their network and forest paths at different scale levels. However, the landscape has become vulnerable due to intensive land use and traffic volume. Consequently, due to the combined effects of natural and anthropogenic disturbances, the habitat for different species may be lost, fragmented or degraded, leading to the formation of a mosaic or patches habitats with changing characteristics. These habitat patches or matrices can facilitate or prevent the movement of species between individual or populations. Because landscapes are spatially heterogeneous and temporally dynamic, it is important to understand how landscape features affect the dispersal, migration, and daily movements of wild animals (Taylor et al., 1993; With et al., 1997; Crooks and Sanjayan, 2006).

In recent years, the scientific world has planned to bring together independent spatial spaces along with their ecological processes to define strategies for the conservation of natural areas (Burkey, 1989; Carroll et al., 2004; Gurrutxaga et al., 2010). Eco-regional landscape planning plays an important role in the natural conservation policies and strategies because of the need to unite the socio-economic and ecological conservation areas of a whole region (Bennett, 2004; Gurrutxaga et al., 2010). Eco-regional landscape planning approaches, also known as ecological networks, constitute the most important step for the development of appropriate and functional protection of wildlife populations. Ecological networks are formed through landscape planning to develop corridors that connect and create a matrix of natural areas (Bennett, 2004; Huber et al., 2007; Gurrutxaga et al., 2010).

The behavior of a wild animal in the landscape varies depending on the structure of the land and its the ecological profile; these structures affect the animals', mobility and perception of the land. In other words, the connection may not be a corridor for all species the movement of species are difference within landscape (Forman, 1995; Tischendorf and Fahrig, 2000). Therefore, the design of ecological corridors, which are planned as eco-regional, takes into account the target species or umbrella species (Noss and Daly, 2006; Hepcan et al., 2009; Gurrutxaga et al., 20I0; Kramer-Schadt et al., 20I I; Dehaghi et al., 20I8; Farrell et al., 20I8). Different empirical models are used in the planning of landscape connections. The most commonly used models in recent years have been those that are built on resistance (Verbeylen et al., 2003; Cushman et al., 2010; Koen et al., 20I0; Zeller et al., 20I2; Zeller et al.,
20I4; Shirk et al., 20I5). The resistance is used to fill in the gaps in the motion information by providing a quantitative estimate of how environmental parameters affect animal movements. The most widely used environmental variables in the formation of resistance surfaces are land use/cover, roads, topographic structure and human settlement areas (Zeller et al., 20I2). Gülci and Akay (20I5) used GIS-based multi-criteria analysis to find ecological passage locations on roads, and suitable movement corridors for roe deers (Capreolus capreolus). Resistance surfaces represent hypothesized relationships between landscape properties and gene flow and are based on biological functions such as relative abundance or movement possibilities in different types of land cover (Zeller et al., 20I2). The difficulty in calculating resistance surfaces is to value to landscape.

Experts have focused on maps using GIS models to connect to the research and conservation plans (Baldwin et al., 2010; Spencer et al., 2010; Gurrutxaga et al., 2010; Mcrae et al., 2012). Raster-based least-cost paths analysis techniques are commonly used to evaluate functional connectivity by modeling the effect of permeability to species movement in the landscape matrix (Adriaensen et al., 2003; Larkin et al., 2004; Clevenger and Wierzchowski, 2006; Gurrutxaga et al., 2010; Watts et al., 2010; Cushman et al., 2018). Developing these models involves defining the "core" or "source" and assigning resistance values to surrounding landscape properties (Stevenson et al. 20I4). For example, Walker and Craighead (1997) used leastcost paths to simulate the dispersal corridor by calculating the the cumulative cost surface based on the habitat preferences of many target species, including grizzly bears, mountain lions and elk in Montana. Identifying how the target species move within the landscape is necessary for effective conservation and management. Using least-cost paths, it is possible to define potential dispersal areas, in addition to evaluate major barriers (Stevenson et al. 20I3).

In this study, we evaluated connectivity for the lynx, a target species in the steppe forest of central of Turkey. We conducted this study to achieve two goals; i) to identify the spatial location of landscape corridors in order to create ecological networks among the natural landscape reserves in the Northern Central Anatolia Region and ii) to develop a guideline that can be applied for landscape connectivity in fragmented areas. The framework represented in this study can be applied to protect biodiversity at different spatial scales.

\section{MATERIALS AND METHODS}

\section{Study Area and Data Set}

The study area was located in the North Central Anatolia in Turkey and covers an area of approximately $10.000 \mathrm{~km}^{2}$. The mountains Elmadağ, Küre Boğazı, Idris, 
Flower, Dinek, and Karagüney are important natural reserves or refuges within the study area. Annual total precipitation of the site is between $395-500 \mathrm{~mm}$ and average temperature is $10^{\circ} \mathrm{C}$. The region is located in the Iran-Turan vegetation zone. The region consists mainly of pasture and agricultural lands. There are large and small forest areas as relic within the study area. There are commonly seen in central Anatolian steppes, oak (Quercus pubescens Willd.), Black pine (Pinus nigra Arn. subsp. Nigra) within the forest sections of the site. The Kızlırmak, Turkey's longest river, flows across the region forming. a longitudinal riparian habitat that irrigates and is affected by surrounding agricultural areas. In addition, the Delice River, the Tüney River and the Balaban Stream are important rivers. The study area includes two provincial centers ( 80.000 and 200.000 persons), 15 district centers (2.000-25.000 persons) and more than five hundred villages (75-I500 persons). the average population density is high in urban and low in rural areas (2-10 person $\left./ \mathrm{km}^{2}\right)$. One of Turkey's highest traffic volume highways, the AnkaraSamsun Highway, runs through the study area the average traffic volume is 55000 vehicle/day.

In the study, the data about the focus species was collected through a review of the literature along with survey data, illegal hunting data and wildlife-vehicle collision data. Forest maps and CORINE maps were used in the classification of land uses. Average daily traffic density, road and railway line data sets were used for the transportation network. The study scale was I: 25,000 and the raster cell resolution was $30 \mathrm{~m}$.

Model

Connectivity is one dependent feature that forms a general landscape mosaic. Therefore, this approach is the selection of target species that can be used as the basis for the design of ecological corridors between protected areas (Gurrutxaga et al., 2010). The behavior of a species in the landscape includes many elements-from the movement of the species to its heterogeneity within the landscape. The landscape connectivity can vary for species. For this reason, the planning of landscape corridors, umbrella species, specific species with large home range, were combined to ascertain the the movement of species in relation to the landscape characteristics (Bani et al., 2002; Bruinderink et al., 2003; Carroll, 2006; Noss and Daly, 2006).

Medium or large mammal species, which often prefer forested areas, were selected as the focal group for creating landscape connectivity between the core areas. The lynx (Lynx lynx; Figure 2) was chosen as the target species because it has remained as relict species in the forest-steppe region of the Küre Boğazı Mountain.

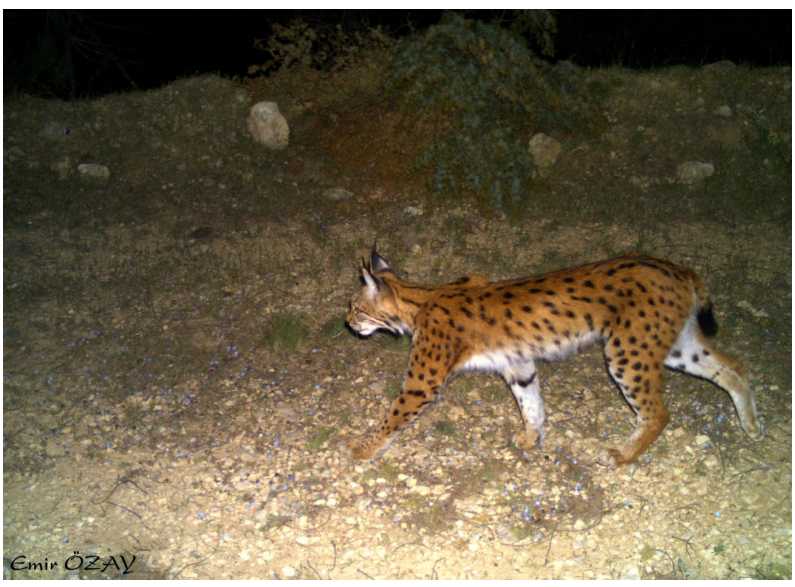

FIGURE 2 Lynx lynx (Photo: Emir ÖZAY).

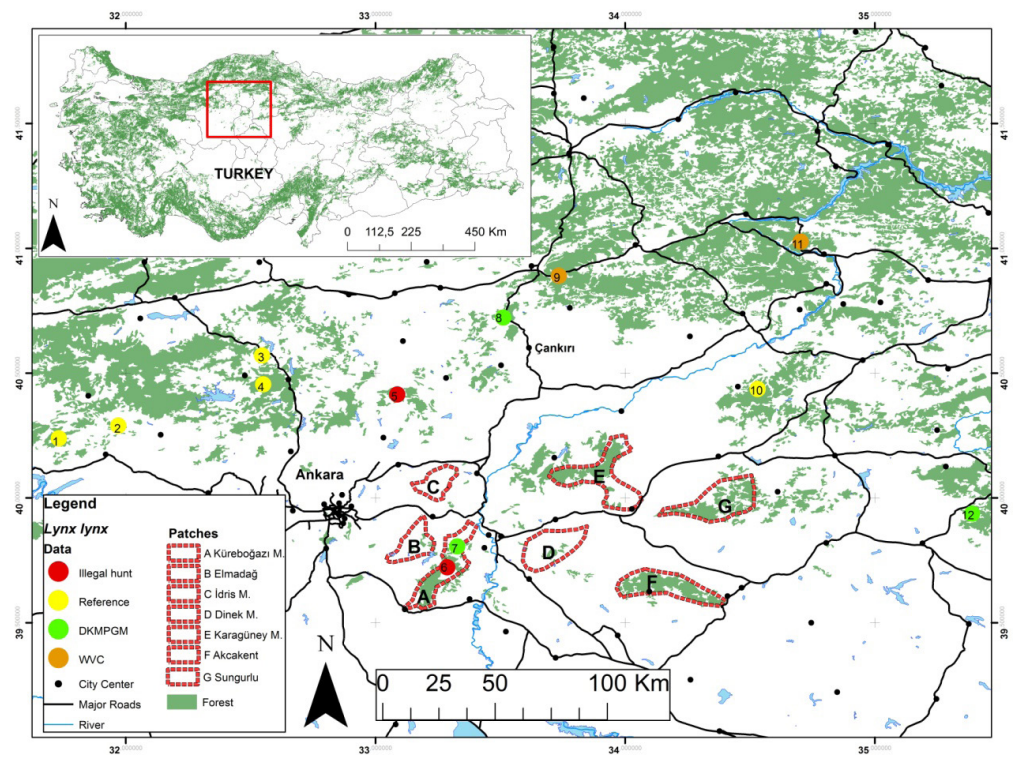

FIGURE I Study area. 
The lynx is the biggest cat in almost all areas in Asia and Europe. Although lynx, due to its wide distribution, has the least concern, some of the its subpopulations in Europe and southwest Asia are fragmented and endangered (Breitenmoser et al., 2008). The diet of most lynx in the forest-steppe landscape mosaic consists of hares.

TABLE I Lynx records for core areas and surroundings.

\begin{tabular}{|c|c|c|c|c|c|}
\hline No & City & Location & $\begin{array}{c}\text { Source } \\
\text { data }\end{array}$ & Date & References \\
\hline I & Ankara & Nallıhan & Reference & & $\begin{array}{l}\text { Mengüllüoğlu et al. } \\
(2018)\end{array}$ \\
\hline 2 & Ankara & Beypazarı & Reference & & $\begin{array}{c}\text { Mengüllüoğlu } \\
(2010)\end{array}$ \\
\hline 3 & Ankara & Çamlıdere & Reference & & Akbaba $(2010)$ \\
\hline 4 & Ankara & Kızılcahamam & Reference & & $\begin{array}{c}\text { Akbaba and Ayaş } \\
(2017)\end{array}$ \\
\hline 5 & Ankara & $\begin{array}{c}\text { Yukarı } \\
\text { Cavundur }\end{array}$ & Illegal hunt & $15 / 09 / 2009$ & Anonymous (2009) \\
\hline 6 & Ankara & $\begin{array}{l}\text { Bala (Küre } \\
\text { Mountain) }\end{array}$ & İllegal Hunt & $20 / 11 / 2014$ & Anonymous (2014) \\
\hline 7 & Kırıkkale & $\begin{array}{c}\text { Küre } \\
\text { Mountain }\end{array}$ & DKMPGM & $10 / 11 / 2015$ & Anonymous (2015a) \\
\hline 8 & Çankırı & Korgun & DKMPGM & $04 / 01 / 2018$ & Anonymous (2018) \\
\hline 9 & Çankırı & Ilgaz & WVC & $17 / 03 / 2016$ & Anonymous (2016) \\
\hline 10 & Çorum & Uğurludağ & Reference & & Bulut et al. (2017) \\
\hline II & Çorum & Osmancık & WVC & $12 / 05 / 2017$ & Anonymous (2017) \\
\hline 12 & Yozgat & $\begin{array}{l}\text { Sorgun } \\
\end{array}$ & DKMPGM & $15 / 03 / 2015$ & Anonymous 2015b) \\
\hline
\end{tabular}

Ecological connections depend on the mobility and ecological needs of wildlife species, as well as landscape structure; the scale of the corridor includes the scale of the landscape structure perceived by species (Foppen et al., 2000). The landscape structure of the region has changed due to the fragmentation and reduction of the forest, the increase in agricultural lands, the expansion of human settlement areas and the increase of a transportation network. The changes in the landscape have led to a reduction or destruction of natural ecological connections. While selecting the core areas in the study area, refuge areas where relic forests are located were taken into consideration. Since these areas are have remained largely undistrubed, they serve as special conservation areas because they have the largest number of species and the highest possibility of maintaining ecological stability (Gaston et al., 2008). The core areas are spatially separated, thus they yield more useful results even if they are close to each other (Gaston et al., 2006). The potential distribution of the target species in the study area goes beyond the core areas, because there are sufficient habitats in the landscape matrix. However, when creating an ecological network model, only the central areas are used as a point of origin. The least-cost model was used to determine the location of the corridors by using resistance maps between the core areas (Adriaensen et al., 2003; Larkin et al., 2004; Clevenger and Wierzchowski, 2006; Gurrutxaga et al.,
20I0). In the design of ecological corridors, to facilitate landscape connectivity, resistance map was prepared based on the assumption that the landscape matrix affected or limited the mobility of the target species. There are two different confusing about mapping connectivity with landscape resistances. First, which environmental variables were selected, and secondly, how much will the resistance values be? The selection and grading of resistance variables in resistance models are very important. Since 1980, many variables have been used for habitat suitability indexes (Zeller et al., 20I2). Many different variables are used in determining the landscape resistance. Landscape resistance can be determined only by an environmental variable that has a land use, as well as an environmental variable between 2-5 variables. This study identified environmental variables known to affect the movement of a target species including land uses, transportation network and hydrological structure. These variables were used calculating resistance surfaces as described by Gurrutxaga et al. (2010) and Zeller et al. (2012). For the determination of land uses for the resistance map, CORINE and Forest maps were used. As a result, seven different land uses were classified within the study area: forest, pasture, agricultural area, mine sites, settlement, water surfaces and rivers.. The roads were classified according to traffic volume and were divided into five groups (Table 2). In the next phase, environmental variables were scored. Of course, resistance values are important, but when scoring, it is more important to correctly sort the effects of environmental variables. Therefore, wildlife experts were asked to sort environmental variables according to the lynx's ease of movement. Variable rankings of wildlife experts and rankings in some studies (Zimmermann and Breitenmoser, 2007; Gurrutxaga et al., 2010) were the same. We used the values between $0-1000$ in order to determine the degree of resistance alike previous studies (Zimmermann and Breitenmoser, 2007; Gurrutxaga et al., 2010). Thus, we thought to increase the sensitivity of the resistance map. We investigated and adapted scientific studies for the lynx about resistance values of variables. For the resistance values of variables, we consulted scientific studies (Ferreras, 200 I; Adriaensen et al., 2003; Carroll, 2006; Zimmermann and Breitenmoser, 2007; Hetherington et al., 2008) and wildlife expert opinion on the lynx. Since, lynx needs forested areas to survive and tends to avoid open areas, we decided that have a positive effect of forest habitats and negative effect of open areas, anthropogenic landscapes, settlement and road for connectivity. However, natural forests were 
considered to be the lowest value (Value $=10)$, urban settlements, mines and lakes are impermeable and highest values $($ Value $=1000)$. Roads were evaluated according to average traffic volume and areas with viaducts or large bridges were rated according to land use. Thus, all layers wereno overlap. The values for the variables were given in detail in Table 2.

In the application of the Least-cost model, the Cost Distance tool of the ArcGIS 10.3 map program (ESRI,20I5) was used. The Cost Distance tool creates an output raster. This output raster is assigned the accumulated cost to the nearest source cell. The algorithm uses the node / link cell representation used in graph theory. Each connection has an impedance. The impedance is obtained from the costs conjunction with the cells at each end of the connection, and from the direction of movement between the cells. A cost is assigned to each cell. The final value per cell is the product of the cell size multiplied by the cost value. The cost of traveling between one node and the next depends on the spatial direction of the nodes. How the cells are connected also affects the cost of travel (ESRI, 20I5).

All combinations between each core area and other core areas were calculated. The width of the corridor was only one pixel. The least cost path should be interpreted as a potential pathway that minimizes the cost of mobility, rather than the functional expression of the dispersal process (Walker and Craighead, 1997; Theobald, 2006; Gurrutxaga et al., 2010). After determining the potentia corridors connecting the core areas and the lynx habitats, we evaluated the major barrier for lynx in regard to the land uses and resistance surfaces.

\section{RESULTS AND DISCUSSION}

The lynx is the biggest cat living in Central Anatolia and it is threatened with extinction in Turkey. The lynx is of the least concern category according to IUCN criteria (Breitenmoser et al., 20I5). To date, there has

TABLE 2 Resistance values (Adapted from Ferreras, 200 I; Carroll, 2006; Zimmermann and Breitenmoser, 2007; Hetherington et al. 2008; Gurrutxaga et al. 2010).

\begin{tabular}{|c|c|c|}
\hline Factor & Sub-factor & Resistance value \\
\hline \multirow{7}{*}{ Land use } & Urban & 1000 \\
\hline & Industrial & 1000 \\
\hline & Water & 1000 \\
\hline & Quarries & 1000 \\
\hline & Crops & 60 \\
\hline & Grassland & 40 \\
\hline & Forest & 10 \\
\hline \multirow{5}{*}{ Roads } & $<1000$ vehicle/day & 80 \\
\hline & I000-5000 vehicle/day & 100 \\
\hline & $5000-10000$ vehicle/day & 300 \\
\hline & $10000-20000$ vehicle/day & 700 \\
\hline & $>20000$ vehicle/day & 800 \\
\hline \multirow{2}{*}{ Rivers } & Large river (>30 m width) & 120 \\
\hline & Medium river ( $<30 \mathrm{~m}$ width) & 40 \\
\hline
\end{tabular}

been no study on population numberr of lynx in Turkey. The General Directorate of Nature Conservation and National Parks (DKMPGM), which is responsible for wildlife, tries to reveal only the lynx distribution with presence-absence. The lynx population in Küreboğazı Mountain has been monitored for the last five years by DKMPGM and the number of lynx is unknown. It is known that the lynx lived in the study area, especially in the Karagüney Mountains (Sulakyurt) (Huş and Göksel 198I). Over time, lynx declined from the core areas. Now it remains only as a remnant in Küreboğazı Mountain. It is certain that the lynx have been in Küreboğazı for a long time. Although the exact number is unknown, there are at least four lynx. At the same time, this region forms the innermost part where the lynx is inserted into the steppe zone.

As long as lynx are preserved, their number will increase. Although the study center is Küreboğazı, the main lynx dispersal will be from the northern part, where the population is higher. We have found evidence of this in the study area. We found roe deer populations both in İdris Mountain and in the Karagüney Mountain. There were no roe deer in both mountains before. After all, one of the reasons for the planning of the corridors is to ensure that the lynx dispersal. Zimmermann et al. (2005) for explaining the cause of dispersal presented three main hypotheses such as prevention of close kinship (Wolff, 1994), competition for breeding (Dobson, 1982) and competition for food (Greenwood, 1980). Zimmerman and Breitenmoser (2007) stated that the Eurasian lynx has not reached the desired population density after entering the Swiss Alps and Jura mountains in the 1970s. The most important reasons for slow dispersaling can be ecological, anthropogenic or anatomical. Therefore, the dispersal process of lynx can be expected to be slow.

Resistance provides an excellent tool for modeling surfaces, corridors or reserves. Resistance surfaces are also one of the most direct ways to applied the resource management and conservation decisions. Three main indicators and fourteen sub-indicators were used to determine the landscape resistances for the target species species in the current study. The corridors calculated by cost path analyzes may not be the most appropriate connection between the two patches, but the analysis of the findings can provide a relative measure to compare the link between different patches (Ferreras, 200I). The accuracy rate depends on the connection of the landscape and consequently decreases due to roads and anthropogenic landscapes (Saunders et al. 2002). The lowest values in the landscape resistances were natural habitats (forest and grassland). Squires et al. (20/3) 
indicate that the Canada lynx selected home ranges at midelevations with low surface roughness and high canopy cover. Lynx avoided forest openings and low canopy cover as has been reported by Murray et al (1994). The highest values, the highest landscape resistance was urban (Kırıkkale and Çankırı provincial centers).

Transportation networks fragment natural habits and are one of the most important threats to the survival of wildlife species. Roads can prevent movement of species from one population to another and thereby disrupts the gene flow of wild animals across a landscape; furthermore, the gene pool is reduced as a result of wildlife vehicle collision (Forman and Alexander 1998; Özcan and Özkazanç 2017). luell et al. (2003) defined five infrastructures/traffic density class for the impact of traffic on wildlife. In the study area, the highways were classified according to traffic volume and high traffic volume (vehicle/day) had the highest resistance values. The traffic volume of Ankara-Samsun Highway is approximately 55.000 vehicles/day. The highest resistance value is also taken by this route line. Village roads with very little traffic volume have limited barrier effect on invertebrates. Mammals use these roads as corridor or for dispersal. Incidental wildlife deaths may occur on roads with a density below 1000 vehicles per day. Therefore, village roads have the lowest resistance values. Zimmerman and Breitenmoser (2007) stated in the study area in the Jura Mountains that the lynx with radio collar were accustomed to crossing the highways.

After the resistance map was created, we calculated the distance based on the matrix quality using the ArcGIS least-cost path tool (Figure 2). Wildlife corridors help to the least cost to an individual wild animal when follow a pathway between core patches. We identified the Küreboğazı core area, where the lynx are found, as the starting point and the center. First we combined the points of the lynx living in the northern forest border with the center. Thus, we established the connection between the lynx populations in the northern forests and the Küreboğazı core area. Then we created the corridors between the other core areas within our field of study. A total of six corridors were created (Figure 2). The shortest corridor in the study area was $16.65 \mathrm{~km}$ long, between the Küreboğazı and Elmadağ core areas. The longest corridor was $145.09 \mathrm{~km}$ long between the Kürebazı core area and Uğurludağ, located at the northern forest border. The routes and lengths of the corridors were given in detail in Table 3. A dispersing young lynx in unsuitable habitat was spent a lot of time, traveled at least $3 \mathrm{~km}$ and came back at a highway. In addition, the lynx has moved away about $21 \mathrm{~km}$ from its home habitat and has traveled $56 \mathrm{~km}$ from an area with less than $20 \%$ forest and shrub for it (Zimmermann \& Breitenmoser 2002). Zimmerman et al. (2007) stated that the lynx in the Jura and North-West Alps traveled up to $164 \mathrm{~km}$ and reached a maximum distance of 75.7 $\mathrm{km}$. The corridor distance is not too long for the lynx to dispersal. The AE corridor with the longest distance (Küreboğazı-Karagüney Mountain-Uğurludağ) consists of two parts. The radio-tagged lynx remained close to human settlements or main roads if they could find safe daily rest places (Zimmermann \& Breitenmoser 2007). Roads and railways for the movement of the lynx on the Jurassic Mountain did not create a barrier if not in wide open landscapes (Breitenmoser et al., 2007). AC corridor (Küreboğazı-İdris Mountain-Çavundur) contains the least anthropogenic landscape compared to other corridors. Therefore, it may higher most likely to be used comparing to others for lynx. These connectivity was potentially corridor represented among the core areas, because they generally used forested areas to be preferred by the lynx. This approach allowed the corridors to pass through areas of low human population density, thus avoiding a significant disturbance. The fragmented structure and the degree of forest fragmentation are also important because fragmented areas are used only for passage. The home range of lynx can include isolated forest patches in open landscape (Haller and Breitenmoser 1986).

Roads and large rivers normally function as major home range limits for lynx (Schadt et al. 2002). Bassile et al. (2009) stated that human density and urban areas have limited the niche of the lynx. For this reason, the habitat of lynx should not be divided by roads and urban uses. Nevertheless, it is certain that human settlements affecting the corridors and critical areas, identified in the study area, will expand in the future. Therefore, real estate, industrial development plans and infrastructure projects for corridors have become the main focus in environmental assessments. In Spain, for example, some local and sub-regional planned urban developments were rejected (Gurrutxaga et al., 2010). Ankara is the second largest city of Turkey. The highway between Ankara and Kırıkkale has a high traffic volume. The problem is not just traffic flow. The main problem is the increase of human settlements and industrial areas at the edges of the road. Because lynx can cross roads. It is impossible to close the road, but at least some areas of the road must be closed to the settlement. Yet there is no such law enforcement in Turkey.

It may be possible to reduce landscape resistance values with increasing reforestation at this area of Central Anatolia. Besides, much of potential corridors were 
created through natural areas. Hetherington et al. (2008) explained that linear barriers were the main reason for the high cost of planning. However, it is inevitable that wildlife corridors intersect with major barriers. There are major barriers to the target species on the landscape corridors. These major barriers are detailed in Table 3.

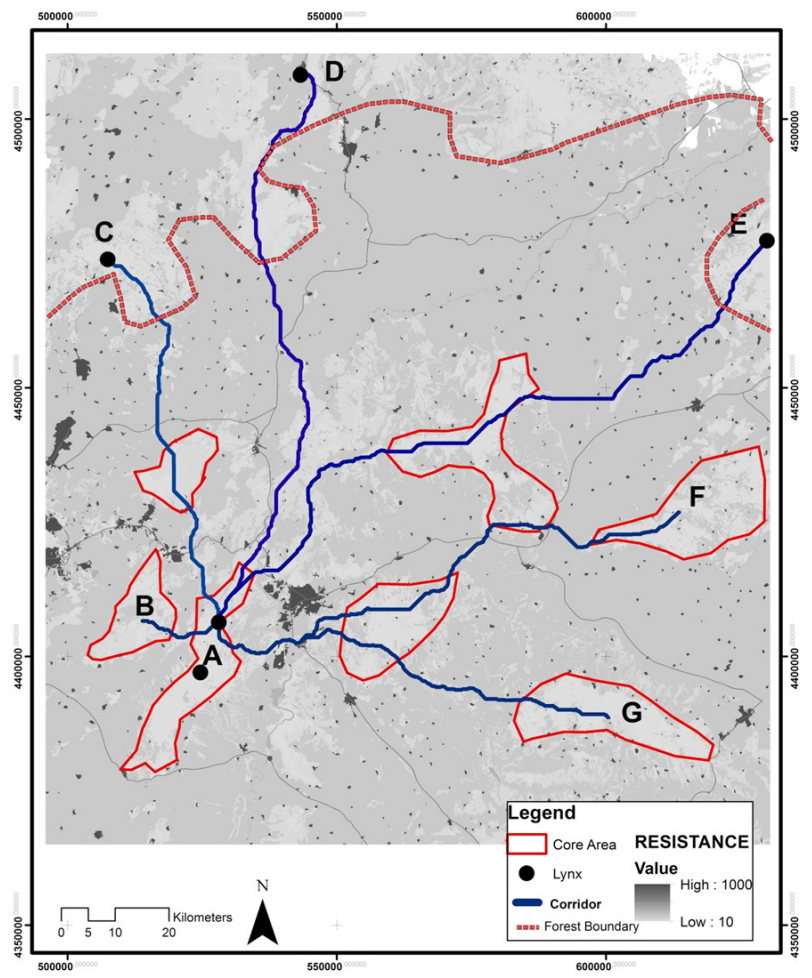

FIGURE 3 Resistance maps and corridors.

Ankara-Kırıkkale Highway is the largest barrier for corridors between Küreboğazı core area and the other core areas and forests in the north. Apart from this highway, it is considered as a major barrier due to high traffic volume in Kırıkkale-Kayseri Highway and KırıkkaleSamsun Highway. In transportation policies, it is important to guarantee the permeability of highways for wildlife as roads with fence and high traffic density often have a significant barrier impact (Clevenger and Wierzchowski, 2006). Therefore, in interactions of highways with potential ecological corridors, it is necessary to ensure that adequate number of appropriate crossing points are established to ensure the spread of medium-large mammals (luell et al., 2003; Gülci and Akay, 2015).

\section{CONCLUSIONS}

Landscape corridors are an important connectivity for the wildlife community that provides flexibility to move against habitat fragmentation. The connection between core areas for isolated European lynx populations should
TABLE 3 Potential corridors and mojor barriers

\begin{tabular}{|c|c|c|c|}
\hline Code & Connection & $\begin{array}{l}\text { Leght } \\
(\mathrm{km})\end{array}$ & Major Barriers \\
\hline$A B$ & Küreboğazı-Elmadağ & 16.65 & \\
\hline $\mathrm{AC}$ & Küreboğazı-Idris Dağı-Cavundur & 87.36 & Two highway \\
\hline$A D$ & Küreboğazı-Korgun & $|08.6|$ & $\begin{array}{c}\text { Two highway, } \\
\text { major river } \\
\text { (Kızılırmak) }\end{array}$ \\
\hline$A E$ & $\begin{array}{l}\text { Küreboğazı-Karagüney } \\
\text { Mountain-Uğurludağ }\end{array}$ & 145.09 & $\begin{array}{c}\text { One highway, } \\
\text { two major river } \\
\text { (Kızilırmak, } \\
\text { Delice) }\end{array}$ \\
\hline AF & $\begin{array}{c}\text { Küreboğazı-Dinek Mountain- } \\
\text { Sungurlu }\end{array}$ & $121.0 \mid$ & $\begin{array}{l}\text { Two highway, } \\
\text { two major river } \\
\text { (Kızılırmak, } \\
\text { Delice) }\end{array}$ \\
\hline AG & $\begin{array}{c}\text { Küreboğazı-Dinek Mountain- } \\
\text { Akçakent }\end{array}$ & 80.52 & $\begin{array}{c}\text { Two highway, } \\
\text { major river } \\
\text { (Kızılırmak) }\end{array}$ \\
\hline
\end{tabular}

be developed to ensure gene flow. There is a need to include the behavioral ecology and landscape structure of target species when evaluating the connection type. The reason is that the characteristics of the species are considered as the most important factor in the evaluation of landscape resistance. Resistance maps should be carefully explored in order to create corridors as well as provide biological conservation measures. Our results have identified major barriers on corridors and corridors between core areas. We cannot expect a lynx to find the optimal connection between the two patches, as indicated by the least-cost path analysis. However, the least-costpath analysis provides a relative standart to compare the corridor between different patches. We hope that our study will be regarded as a method for conservation decisions and policies for biological conservation and eco-regional landscape planning. We also hope that this study will be a guide that can be used by researchers and planners to improve and identify corridors.

\section{ACKNOWLEDGMENTS}

This study was supported by Scientifich Research and Project Comission (BAP) of Çankırı Karatekin University under the project number OF0612I8L06. Also, this study was permitted by General Directorate of Nature Conservation and National Parks (DKMPGM) in Turkey. The authors would like to thank Ufuk Özdağ for her grammatical edit of the manuscript and Emre Özay for the lynx photo.

\section{REFERENCES}

ADRIAENSEN, F; CHARDON, J. P.; DE BLUST, G.; SWINNEN, E.; VILLALBA, S. et al. The application of 'least-cost' modelling as a functional landscape model. Landscape and Urban Planning, v. 64, n. 4, p. 233-247, 2003. 
$A K B A B A, B$. Investigation on habitat use and feeding behaviour of the red foxes (Vulpes vulpes L. 1758) in Çamlıdere-Çamkoru region (Ankara). 2010. 101 p. Msc thesis. Hacettepe University, Ankara, Turkey.

AKBABA, B.; AYAŞ, Z. Spatial and temporal distribution of Eurasian Lynx (Lynx lynx L. 1758) in northwestern Turkey. 2017. The 3rd International Symposium on EuroAsian Biodiversity, Minsk, Belarus.

ANONYMOUS. Find to lynx. Available at: http://bolge9. ormansu.gov.tr/ 9bolge/AnaSayfa/resimliHaber/I5II0/ K\% C4\%B I r\%C4\%B I kkale_de_Fotokapanlar Va\%C5\%9Fak_G\%C3\%B6r\%C3\%BCnt\%C3\%BCledi. aspx?sflang $=$ tr. Accessed in: $0 \mathrm{I}$ july 2015.

ANONYMOUS. Hunted to lynx. Available at: http://www. milliyet.com.tr/ilgaz-da-nesli-tukenmekte-olan-vasakcankiri-yerelfotogaleri- I3880047/. Accessed in: 0I july 20 I8.

ANONYMOUS. Lynx. Available at: http://bolge9.ormansu.gov. tr/9bolge/anasayfa/resimlihaber/I3-0I-I5/. Accessed in: 0 I September 2015.

ANONYMOUS. Lynx. Available at: http://www.hurriyet.com. tr/kacak-vasak-avlayan-avciya-6-bin-tl-ceza-370I I659. Accessed in: 01 july 2018.

ANONYMOUS. Lynx. Available at: http://www.milliyet.com.tr/ anakara-da-nesli-tuekenmek-uzere-olan-olu-vasak-bulundumagazin- I I39589/. Accessed in: I5 september 2009.

ANONYMOUS. Lynx. Available at: http://www3.milliparklar. gov.tr /anasayfa/resimlihaber/I8-0I-04/. Accessed in: 01 December 2016.

ANONYMOUS. Traped to lynx. Available at: http://corum. ormansu.gov.tr/corum/AnaSayfa/ resimliHaber/I7-05-I2/r. Accessed in: 01 june 2017.

BALDWIN, R. F.; PERKL, R. M.; TROMBULAK, S. C.; BURWELL, W. B. Modeling Ecoregional Connectivity. In: TROMBULAK, S. C.; BALDWIN, R. F. (editors). Landscape-scale Conservation Planning. Houten, Netherlands: Springer Netherlands, 2010. p. 349-367.

BANI, L.; BAIETTO, M.; BOTTONI, L.; MASSA, R. The use of focal species in designing a habitat network for a low land area of Lombardy, Italy. Conservation Biology, v. 16, p. 826-83I, 2002.

BASILLE, M.; HERFINDAL, I.; SANTIN-JANIN, H.; LINNELL, J. D.; ODDEN, J.; ANDERSEN, R.; ... \& GAILLARD, J. M. What shapes Eurasian lynx distribution in human dominated landscapes: selecting prey or avoiding people?. Ecography, v. 32, n. 4, p. 683-69I, 2009.

BENNETT, G. Integrating biodiversity conservation and sustainable use: lessons learned from ecological networks. Gland, Switzerlandand Cambridge, UK: IUCN. 2004.
BREITENMOSER, U.; BREITENMOSER-WURSTEN, C.; CAPT, S.; MOLINARI-JOBIN, A.; MOLINARI, P., ZIMMERMANN, F. Conservation of the lynx Lynx lynx in the Swiss Jura Mountains. Wildlife biology, v. I3, n. 4, p. 340-355. 2007

BREITENMOSER, U.; BREITENMOSER-WURSTEN, C.; LANZ, T.; VON ARX, M.; ANTONEVICH, A.; BAO, W.; AVGAN, B. Lynx lynx (errata version published in 20I7). The IUCN Red List of Threatened Species, e.TI25I9AI2I707666. 2015.

BREITENMOSER, U.; BREITENMOSER-WÜRSTEN, C.; JOBIN, A. Der Luchs. Salm-Verlag, 2008.

BRUINDERINK, G.; VAN DER SLUIS, T.; LAMMERTSMA, D.; OPDAM, P.; POUWELS, R. Designing a coherent ecological network for large mammals in northwestern Europe. Conservation Biology, v. 17, p. 549-557, 2003.

BULUT, Ş.; AKBABA, B.; KARATAŞ, A. Contributions to the Knowledge of Mammals in Corum Province, Turkey. Hittite Journal of Science and Engineering, v. 4, n. I, p. 57-63, 2017.

BURKEY, T. V. Extinction in nature reserves: the effect of fragmentation and th importance of migration between reserve fragments. Oikos, v.55, p. 75-81, 1989.

CARROLL, C. Linking connectivity to viability: insights from spatial explicit population models of large carnivores. In. CROOKS, K. R.; SANJAYAN, M. (Editors), Connectivity Conservation, Cambridge: Cambridge University Press, 2006. p. 369-389.

CARROLL, C.; NOSS, R. F.; PAQUET, P. C.; SCHUMAKER, N.H. Extinction debt of protected areas in developing landscapes. Conservation Biology, v. I8, p. I I I0- | I 20, 2004.

CLEVENGER, A.P.; WIERZCHOWSKI, J. Maintaining and restoring connectivity in landscapes fragmented by roads. Conservation Biology Series-Cambridge, v. I4, p. 502, 2006.

CROOKS, K.R.; SANJAYAN, M. Connectivity conservation. Cambridge University Press, v. I4, 2006.

CUSHMAN, S. A.; CHASE, M.; GRIFFIN, C. Mapping landscape resistance to identify corridors and barriers for elephant movement in southern Africa. In Spatial complexity, informatics, and wildlife conservation, Springer, Tokyo. 2010, p. 349-367.

CUSHMAN, S. A.; SHIRK, A. J.; HOWE, G. T.; MURPHY, M. A.; DYER, R. J.; JOOST, S. eds. The Least Cost Path From Landscape Genetics to Landscape Genomics: Challenges and Opportunities to Explore NGS Data in a Spatially Explicit Context. Frontiers Media, 2018. p. 215.

DEHAGHI, I. M.; SOFFIANIAN, A.; HEMAMI, M. R.; POURMANAFI, S.; SALMANMAHINY, A. et al. Exploring structural and functional corridors for wild sheep (Ovis orientalis) in a semi-arid area. Journal of Arid Environments, v. 156, p. 27-37, 2018. 
DOBSON, F. S. Competition for mates and predominant juvenile male dispersal in mammals. Animal Behaviour, v. 30, n.4, p. II83-II92, 1982.

ESRI (Environmental Systems Research Institute). (20I5). ArcGIS 10.3. I for desktop.

FARRELL, L.E.; LEVY, D.M.; DONOVAN, T.; MICKEY, R.; HOWARD, A. et al. Landscape connectivity for bobcat (Lynx rufus) and lynx (Lynx canadensis) in the Northeastern United States. PloSone, v. I3, n.3, e0194243, 2018.

FERRERAS, P. Landscape structure and asymmetrical inter-patch connectivity in a metapopulation of the endangered lberian lynx. Biological Conservation, v. I00, n. I, p. I25-I36, 200 I.

FORMAN, R. T. T. Some general principles of landscape and regional ecology. Landscape Ecology, v. 10, n. 3, p. I33142, 1995.

FORMAN, R. T. T.; ALEXANDER, L. E. Roads and their major ecological effects. Annual Review of Ecology and Systematics, v. 29, n. I, p. 207-23I, 1998.

GASTON, K. J.; CHARMAN, K.; JACKSON, S. F; ARMSWORTH, P. R.; BONN, A. et al. The ecological effectiveness of protected areas: the United Kingdom. Biological Conservation, v. I32, n. I, p. 76-87, 2006

GASTON, K. J.; JACKSON, S. F; CANTÚ-SALAZAR, L.; CRUZPIÑÓN, G. The ecological performance of protected areas. Annual Review of Ecology, Evolution and Systematics, v. 39, p. 93-II3, 2008.

GREENWOOD, P. J. Mating systems, philopatry and dispersal in birds and mammals. Animal Behaviour., v. 28, p. I | 40 II62, 1980.

GURRUTXAGA, M.; LOZANO, P. J.; DEL BARRIO, G. GISbased approach for incorporating the connectivity of ecological networks into regional planning. Journal for Nature Conservation, v. 18, n. 4, p. 318-326, 2010.

GÜLCI, S; AKAY, A. E. Assessment of ecological passages along road networks within the Mediterranean forest using GISbased multi criteria evaluation approach. Environmental Monitoring and Assessment, v I87, n 12, p. 779, 2015.

HALLER, H.; BREITENMOSER, U. Zur Raumorganisation der in den Schweizer Alpen wiederangesiedelten Population des Luchses (Lynx lynx). Zeitschrift für Säugetierkunde, v. 5I, n. 5, p. 289-3II, 1986.

HEPCAN, Ş.; HEPCAN, Ç. C.; BOUWMA, I. M.; JONGMAN, R. H.; ÖZKAN, M. B. Ecological networks as a new approach for nature conservation in Turkey: a case study of Izmir Province. Landscape and Urban Planning, v. 90, n. 3, p. 143-154, 2009.

HETHERINGTON, D. A.; MILLER, D. R.; MACLEOD, C. D.; GORMAN, M. L. A potential habitat network for the Eurasian lynx Lynx lynx in Scotland. Mammal review, v. 38, n. 4, p. 285-303, 2008.
HUBER, P. R.; ROTH, N. E.; BEARDSLEY, K.; THORNE, J. H.; MCCOY, M. C. et al. Potential impacts of urban growth on an ecological network in the San Joaquin Valley. San Francisco: Association for American Geographer's, 2007.

HUŞ, S.; GÖKSEL, E. Türkiye av hayvanlarının yayılış yerleri. İstanbul Üniversitesi Orman Fakültesi Dergisi, v. 31, n. 2, p. 68-81, 1981.

IUELL, B. Wildlife and Traffic-a European handbook for identifying conflicts and designing solutions. In The XXIInd PIARC World Road CongressWorld Road Association-PIARC, 2003.

KOEN, E. L.; GARROWAY, C. J.; WILSON, P. J.; BOWMAN, J. The effect of map boundary on estimates of landscape resistance to animal movement. PloSone, v. 5, n. 7, el I 785, 2010.

KRAMER-SCHADT, S.; REVILLA, E.; WIEGAND, T.; KNAUER, F.; KACZENSKY, P.; BREITENMOSER, U.; ... \& STANIŠA, C; (2002). Assessing the suitability of central European landscapes for the reintroduction of Eurasian lynx. Journal of Applied Ecology, v. 39, n. 2, p. I89-203, 2002.

KRAMER-SCHADT, S.; KAISER, T. S.; FRANK, K.; WIEGAND, T. Analyzing the effect of stepping stones on target patch colonisation in structured landscapes for Eurasian lynx. Landscape Ecology, v. 26, n. 4, p. 50I-5।3, 20 II.

LARKIN, J. L.; MAEHR, D. S.; HOCTOR, T. S.; ORLANDO, M. A.; WHITNEY, K. Landscape linkages and conservation planning for the black bear in west-central Florida. In Animal Conservation Forum, Cambridge University Press, v. 7, n. I, p. 23-34, 2004.

MCRAE, B. H.; HALL, S.; BEIER, P.; THEOBALD, D. M. Where to restore ecological connectivity? Detecting barrier sand quantifying restoration benefits. PloSone, v. 7, n. 12, e52604, 2012.

MENGULLUOĞLU, D. An inventory of medium and large mammal fauna in pine forests of Beypazari through camera trapping. 20I0. Msc thesis. Middle East Techinical University, Ankara, Turkey.

MENGULLUOĞLU, D.; AMBARLI, H.; BERGER, A.; HOFER, H. Foraging ecology of Eurasian lynx populations in southwest Asia: Conservation implications for a diet specialist. Ecology and Evolution, v. 8, n. 18, p. 945I-9463, 2018

MURRAY, D. L.; KAPKE, C. A.; EVERMANN, J. F.; FULLER, T. $K$. Infectious disease and the conservation of free-ranging large carnivores. In Animal Conservation Forum, Cambridge University Press, v. 2, n. 4, p. 24I-254, 1999.

NOSS, R. F.; DALY, K. M. Incorporating connectivity intobroadscale conservation planning. In. CROOKS, K. R.; SANJAYAN, M. (Editors), Connectivity Conservation, Cambridge University Press, Cambridge, 2006. p. 587-619.

ÖZCAN, A. U.; ÖZKAZANÇ, N. K. Identifying the hotspots of wildlife-vehicle collision on the Çankırı-Kırıkkale highway during summer. Turkish Journal of Zoology, v. 4I, n. 4, p. 722-730, 2017 
SAUNDERS, S.C.; MISLIVETS, M.R.; CHEN, J.; CLELAND, D.T. Effects of roads on landscape structure within nested ecological units of the Northern Great Lakes Region, USA. Biological Conservation, v 103, p 209- 225, 2002.

SHIRK, A. J.; SCHROEDER, M. A.; ROBB, L. A.; CUSHMAN, S. A. Empirical validation of landscape resistanc emodels: insights from the Greater Sage-Grouse (Centrocercus urophasianus). Landscape Ecology, v. 30, n. 10, p. 1837 I850, 2015.

SPENCER, W. D.; BEIER, P.; PENROD, K.; PARISI, M.; PETTLER, A. California essential habitat connectivity project: A strategy for conserving a connected California. Prepared for California Department of Transportation, California Department of Fish and Game, and Federal Highways Administration. 2010.

SQUIRES, J. R.; DECESARE, N. J.; OLSON, L. E.; KOLBE, J. A.; HEBBLEWHITE, M. et al. Combining resource selection and movement behavior to predict corridors for Canada lynx at their southern range periphery. Biological Conservation, v. 157, p. 187-195, 2013.

STEVENSON, C. D.; FERRYMAN, M.; NEVIN, O. T.; RAMSEY, A. D.; BAILEY, S. Using GPS telemetry to validate least-cost modeling of gray squirrel (Sciurus carolinensis) movement within a fragmented landscape. Ecology and Evolution, v. 3 , p. $2350-2361,2013$.

STEVENSON-HOLT, C. D.; WATTS, K.; BELLAMY, C. C.; NEVIN, O. T.; RAMSEY, A. D. Defining landscape resistance values in least-cost connectivity models for the invasive grey squirrel: a comparison of approaches using expertopinion and habitat suitability modelling. PloSone, v. 9, n. II, ell2II9, 2014.

TAYLOR, P. D.; FAHRIG, L.; HENEIN, K.; MERRIAM, G. Connectivity is a vital element of landscape structure. Oikos, p. 57I-573, 1993.

THEOBALD, D. M. Exploring the functional connectivity of landscapes using landscape networks. In: CROOKS, K. R.; SANJAYAN, M. (editors) Connectivity conservation. Cambridge University Press, Cambridge, 2006. p. 4I6-443.

TISCHENDORF, L.; FAHRIG, L. How should we measure landscape connectivity? Landscape Ecology, v. 15, p. 633-64I, 2000.

VALENTE, R. A., PETEAN, F. C. D. S.; VetTORAZZI, C. A. Multicriteria decision analysis for prioritizing areas for forest restoration. Cerne, v. 23, n. I, p. 53-60, 2017.
VERBEYLEN, G.; DE BRUYN, L.; ADRIAENSEN, F; MATTHYSEN, E. Does matrix resistance influence Reds quirrel (Sciurus vulgaris $L$. 1758) distribution in an urban landscape? Landscape Ecology, v. I8, n. 8, p. 79I-805, 2003.

WALKER, W.; CRAIGHEAD, F. L. Analyzing wildlife movement corridors in Montana using GIS. 1997. p. I-18. In Proceedings of the 1997 ESRI user conference, Redlands, USA.

WATTS, K.; EYCOTT, A. E.; HANDLEY, P.; RAY, D.; HUMPHREY, J. W. Target ingande valuating biodiversity conservation action within fragmented landscapes: An approach based on generic focal species and least-cost networks. Landscape Ecology, v. 25, p. |305-13 |8, 20 I0.

WITH, K. A.; GARDNER, R. H.; TURNER, M. G. Landscape connectivity and population distributions in heterogeneous environments. Oikos, v. 78, p. 151-169, 1997.

WOLFF, J. O. More on juvenile dispersal in mammals. Oikos v. 7I, p. 349-352, 1994.

ZELLER, K. A.; MCGARIGAL, K.; BEIER, P.; CUSHMAN, S. A.; VICKERS, T. W.; BOYCE, W. M. Sensitivity of landscape resistance estimates based on point selection functions to scale and behavioral state: pumas as a case study. Landscape Ecology, v. 29, n. 3, p. 54I-557, 2014.

ZELLER, K. A.; MCGARIGAL, K.; WHITELEY, A. R. Estimating landscape resistance to movement: a review. Landscape Ecology, v. 27, n. 6, p. 777-797, 2012.

ZIMMERMANN, F; BREITENMOSER, U. A distribution model for the Eurasian lynx (Lynx lynx) in the Jura Mountains, Switzerland. Predicting species occurrences: issues of accuracy and scale, p. 653-659 2002.

ZIMMERMANN, F; BREITENMOSER-WURSTEN, C.; BREITENMOSER, U. Natal dispersal of Eurasian lynx (Lynx lynx) in Switzerland. Journal of Zoology, v. 267, n. 4, p. 38I-395, 2005.

ZIMMERMANN, F.; BREITENMOSER, U. Potential distribution and population size of the Eurasian lynx Lynx lynx in the Jura Mountains and possible corridors to adjacent ranges. Wildlife Biology, v. I3, n. 4, p. 406-416, 2007.

ZIMMERMANN, F; BREITENMOSER-WÜRSTEN, C.; BREITENMOSER, $U$. Importance of dispersal for the expansion of a Eurasian lynx Lynx lynx population in a fragmented landscape. Oryx, v. 4I, n. 3, p. 358-368. 2007 